\title{
ミッションフェローの広場
}

\section{JIEP Mission Fellow}

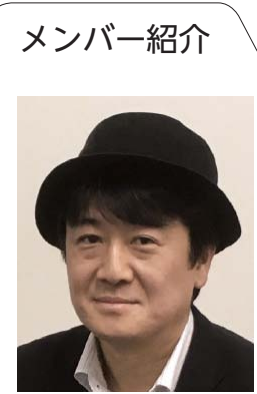

田久真也（たきゅうしんや）

所属 : リンテック株式会社

学会活動：ミッションフェロー, システ ムインテグレーション実装技術委員会, システムインテグレーション実装技術研 究会主査

"Be yourself, no matter what they say..

さしたるキャリア・ビジョンもなく，バブルの波に 乗って東芝に入社し, 聞いた事もない半導体パッケー ジのプロセス技術担当に配属されたのは 1991 年だっ た。国内の半導体メーカが群雄割拠している時代で,

技術者を増員しながら他社をしのぐ新規技術開発にし のぎを削っていた。当時は，評価設備や装置も未成熟 で，今から振り返ると稚拙な開発も多かったように思 うが，手と目を動かしながら，自由度の高い実験が出 来ていた。自分の場合，量産技術担当であったので, 階段を 1 段ずつ着実に積み上げるような技術開発が主 たるミッションではあったが，思いつきのようなアイ ディアにトライ出来たし，そんな試みに協力してくれ る先輩や社外の協力者も多かった。アイディアに失敗 はつきものだが，たまに成功した時のうれしさは格別 で，また新たなトライや，他人と違うことをしょう， と考えるきっかけになっていた。失敗を繰り返すこと が，かけがえのない財産となり，自分なりの新たな発 想を生む原動力になると思う。いまでは東芝を離れ， 材料／装置メーカのリンテックに転職したが, 多くの 失敗経験が，いまでも役に立っていると思う（もちろ ん今でも失敗し続けている)。

冒頭のフレーズは，スティングの “Englishman in New York”の歌詞からの引用であるが，個人が個人と してあるべきことの大事さをいつも思い出させてくれ る。個人が自らのスキルを磨き，そうした人々が集ま ることで, 組織は前進していくものだと思う。いま世 界の半導体産業は活況を呈している。産業として好況 な分，組織目標を早く実践することが求められ，開発 の中に遊びの要素や，失敗出来る余裕が，産学ともに なくなってきているように感じる。実ワークの中で自 分を育てにくい環境になっており，とても残念であ る。しかし, 学会活動やこのミッションフェローの活 動が，多くの人のスキルアップの一助となり，かつ ミッションフェローの個性的なメンバーが異種格闘技 的にぶつかりあう事で，いままでにない技術を生み出 すような，そんな場になれたら良いと思う。

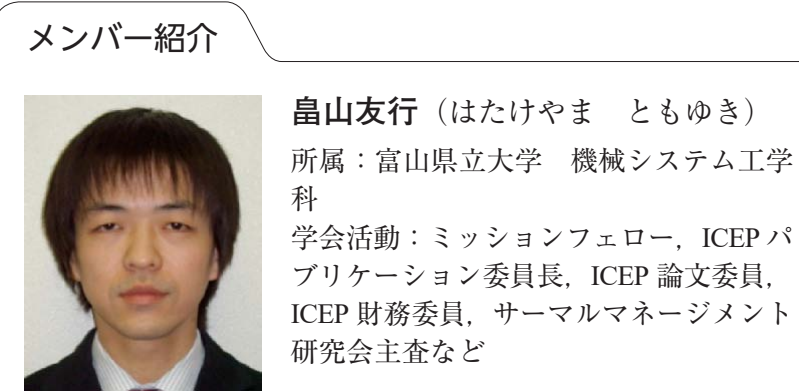

大学を卒業した後, 一年間のポスドク経験を経て富 山県立大学に赴任し, 赴任後まもなく“悪いおじさん たち”に引き込まれる形で, エレクトロニクス実装学 会と関わりを持ちました。今となっては実装学会に どっぷり浸かっており, 第一期からミッションフェ ローとして活動しております。専門は, 電子機器の サーマルマネージメントです。一部の方々は, 私の専 門分野を, 飲み会の司会進行と思っているようです が，まんざら間違いでもありません。

大学教員になった直後から, 周囲の人々に学生気分 が抜けていないとよく言われておりました。いずれ学 生気分は抜けるだろうと思い, なんとなく過ごしてき ましたが，“いずれ”はまだ訪れていないようです。お かげで, 学生との関係は, 教員と学生の関係というよ りも, 先輩と後輩の関係に近い感覚になっており, 非 常に楽しく毎日を過ごせております。この学生との関 係性は非常に良く, 腹を割ったコミュニケーションが できております。そのため, 雲囲気が明るく, 大変な 仕事でもみんなで楽しみながら取り組める環境になっ ております。この雲囲気作りは, ミッションフェロー の集まりに共通するものがあるように感じておりま す。ミッションフェローは, 第一期から雲囲気が明る く, メンバー間で活発な議論をして来ました。また, ミッションフェローのお世話役のエグゼクティブフェ ローの方々も, 同じ目線で話をしてくれるので, 非常 に楽しく活動ができております。ミッションフェロー の集まりは，どんなに難しいことに直面しても，その 状況を楽しんでしまえる場だと思います。明るい䨌囲 気でチームとして動けるミッションフェローの面々 で，互いに成長し，目の前のものだけにとらわれず もっと先を見ながら，前へ進みたいと思います。

冒頭の“悪いおじさんたち”はみんな, 私のような 若輩者に対しても同じ目線で話をしてくれる人ばかり です。私の下した決定でも, 決して否定することはな く, 尊重してくれる方々ばかりです。そういう人たち を見ながら，私も多くのことを学んでおります。私も 先輩たちを見習い，立派な“悪いおじさん”になりた いと思います。 